\title{
Converging HRM practices? A comparison of high performance work system practices in MNC subsidiaries and domestic firms in Pakistan
}

\begin{abstract}
Purpose

Existing work on convergence/divergence amongst HRM practices in MNCs and local firms mainly focuses on Europe and the US. Limited research examines these organizations in Pakistan, hindering our understanding of what policies MNCs are likely to adopt there as well as the extent of any differences between HRM in MNC subsidiaries and local firms. We examine the similarities and differences between the HRM practices of MNC subsidiaries and domestic firms to assess if there is evidence for convergence or divergence.
\end{abstract}

Design/methodology/approach

We targeted MNC subsidiaries and domestically owned firms working in the banking, information technology and pharmaceutical sectors in Pakistan. These sectors have enjoyed a steady inflow of FDI and have a sizeable number of MNC subsidiaries. Out of 1081 companies, some 392 participated in a face-to-face survey (response rate of $36.4 \%$ ). We ran a series of binary logistic regression models to test the hypothesized relationships between HR practices and nationality of ownership.

\section{Findings}

We reveal that a small minority of both types of firm use some practices, such as high compensation contingent on performance and performance review, appraisal and career development. However, domestic firms use some practices, such as extensive training, performance appraisals and performance-related pay significantly less than their 
multinational counterparts. We argue that these differences reflect institutional influences in Pakistan as well as a potential opportunity for local firms to change their HRM practices. In other areas, such as recruitment and employee involvement, there are no differences between the two groups.

\section{Originality/value}

We deepen our understanding of the types of HR practices that local companies in an emerging economy are likely to adopt as well as those that they are unlikely to adopt. Existing research has tended to downplay 1) HRM in Pakistan and 2) the different use of individual HRM practices amongst MNC subsidiaries and local firms. Our research reveals that some companies in Pakistan have sophisticated HRM practices in place in some areas; however, MNC subsidiaries make greater use of some HR practices, reflecting different cultural norms between the two groups. 


\section{Introduction}

An important strand in the HRM literature has long questioned whether a global model of HRM, centred on high performance work systems, will emerge or whether country-specific models will prevail (Budhwar et al., 2016, Chen et al., 2005, Pudelko and Harzing, 2007a, Brewster et al., 2016). Empirical studies have presented convincing evidence to support both positions; the debate, therefore, is far from over. We compare the high performance work system (HPWS) practices and policies of MNC subsidiaries and domestic firms in Pakistan and assess any convergence/divergence amongst these policies.

There is a paucity of literature on HRM in South and South East Asia, especially Pakistan (Budhwar et al., 2016, Ahmad and Allen, 2015), creating a need to understand how the HRM practices of indigenous firms compare to those of MNCs (Chiang et al., 2017; Budhwar et al., 2016).In particular, we examine how domestic cultural factors influence the adoption of HPWS practices in Pakistan between MNC subsidiaries and local Pakistani firms. The lack or inadequate implementation of formal regulations or institutions in Pakistan provide companies with greater discretion over their HRM practices, potentially leading to differences in practices between local and foreign companies (Vaiman and Brewster, 2015).

We hypothesize that cultural differences between the two groups of companies are likely to be more important for some HPWS, such as performance reviews, learning opportunities, and performance-related pay, than for others, such as recruitment and selection, leading to variation in the prevalence of some polices, but not others amongst the two groups. We test these hypotheses against a unique dataset covering the banking, information technology and pharmaceutical sectors in Pakistan. Our findings confirm our hypotheses: domestic firms use some practices, such as extensive training, performance appraisal and contingent pay, significantly less than their multinational counterparts. For other HPWS practices, such as recruitment and employee involvement, there are no 
statistically significant differences between the two groups. We argue that these differences reflect cultural differences between the two groups with connections (or sifarish values) being more important in local firms than MNC subsidiaries.

We contribute to the oft-debated issue of HR policy transfer under the theoretical lens of institutional theory by providing evidence from an important, but under-researched country. We deepen our understanding of the types of HR practices that local companies in an emerging economy are likely to adopt as well as those that they are unlikely to adopt. Existing research has tended to downplay 1) HRM in Pakistan and 2) the different use of individual HRM practices amongst MNC subsidiaries and local firms. Our research reveals that some companies in Pakistan have sophisticated HRM practices in place in some areas; however, MNC subsidiaries make greater use of some HR practices, reflecting different cultural norms between the two groups.

The rest of the paper has three sections. The first section reviews the literature and provides the hypothesis for the study. The second section discusses the methodology and results. The final section discusses our results and concludes.

\section{The Convergence-Divergence debate in HRM}

Globalization has increased interest in the convergence or divergence of firms' HRM practices in different national and cultural settings. Some research finds that, due to a common logic of industrialism, similarities in the organization of work throughout the world are increasing, leading to a convergence of HRM practices around those associated with US MNCs, as such firms are often seen as 'technological leaders' despite the differences in national cultures, politics and ideology (Kerr et al., 1960, Hall and Soskice, 2001, EspingAndersen, 1990). Other research finds that cultural and institutional differences between 
countries and regions prevail, resulting in persistent differences in management systems and practices (Hofstede et al., 2010, House et al., 2004).

In this convergence-divergence debate, HRM scholars have analysed several factors, most notably country-of-origin effects (Almond and Ferner, 2006, Ferner and Quintanilla, 1998) as well as host- and home-country effects (Edwards and Kuruvilla, 2005, Edwards and Zhang, 2008). This research has highlighted the influence of host-country factors, such as local isomorphism, internal consistency, institutional forces, informal controls, social networks, headquarter influence and host-country general environment (Björkman et al., 2007, Fey et al., 2009, Myloni et al., 2007), on HRM practices. Another stream of research has explored the similarities and differences in employment practices in Europe, revealing a general directional similarity in employment practices; however, there is no evidence of complete convergence (Mayrhofer et al., 2011, Poutsma et al., 2006, Sahadev and Demirbag, 2011).

MNCs may not organize the HRM function of their subsidiaries according to countryof-origin or host-country environment rather they can standardize their HRM policies and practices according to the country that sets the standards for what is perceived as global best practices, often the US model of management (Pudelko and Harzing, 2007a). HPWS have attained the status of best practices in HRM that many MNCs adopt in their international operations (Björkman et al., 2007, Brewster, 2011, Mellahi et al., 2013). Smith and Meiksins (1995) in their system-society-dominance model proposed the idea of a dominance effect: the US, Japan and Germany are the countries that provide the best practices for others to follow. Due to globalization and the prominence of the US in the world economy, the US is the technological leader and role model in management. HPWS as a system of best practices for managing human resources has its roots in American history and culture, meaning that they may not be applicable in other countries. However, American-style HPWS influence MNCs, 
in general, and HPWS, in particular, have become the dominant global HR system (Chen et al., 2005, Pudelko and Harzing, 2007a, Tüselmann et al., 2008).

Many scholars have taken HPWS policies and practices as the basis for comparing similarities and differences between MNCs and domestically owned firms within a country or across countries. For instance, Lawler et al. (2011) examined the HPWS practices of US multinationals in 14 countries and found that subsidiaries in affluent, low-growth Western European countries are less likely to implement HPWS than those in emerging East Asian economies. Chen et al. (2005) analysed the similarities and differences between MNC subsidiaries and local firms in relation to HPWS in Taiwan, concluding that the use of HPWS in Taiwan was on the rise. Mellahi et al. (2013) compared the HPWS practices of MNC subsidiaries and local firms in Turkey and argued that specific sociocultural contingencies play an important role in explaining statistically significant differences between the two types of firm. Ma et al. (2016) investigated the HRM practices of multinational and local firms in China, finding that the Chinese institutional context shapes the degree of homogeneity and hybridity of control and commitment HRM system across firms in China. Although there are still differences between countries, the existing evidence suggests that, in general, HPWS practices are gaining acceptance in diverse cultures and institutional set-ups. However, we are not aware of any large-scale studies that examine the HPWS practices of MNC subsidiaries and local firms in Pakistan with its distinctive socio-cultural characteristics.

\section{Convergence-divergence and institutional theory}

Institutional theory is a key theoretical approach to explaining convergence-divergence (Vanhala et al., 2006), suggesting that firms become similar in the same organizational field (Kostova et al., 2008). Firms conform to contextual expectations to gain legitimacy and to survive. Thus, a process of homogenization or 'isomorphism' forces one unit in a population 
to resemble others (Paauwe, 2009). Firms may face coercive, mimetic and normative pressures to look similar (Scott, 2013, Scott, 1995). Coercive isomorphism happens due to regulatory pressures. Mimetic isomorphism results from firms emulating more successful ones and leads to companies in the same organizational field resembling one another. Normative isomorphism stems from socialization and unquestioned assumption about how to organize work (DiMaggio and Powell, 1983, Jackson and Deeg, 2008, Paauwe, 2009). In our context, the arguments of institutional duality may help to explain the similarities and differences between the two types of firms. While MNC subsidiaries may feel pressure to conform to local norms to establish legitimacy in the new context, domestic firms at the same time may feel pressure to adopt to international practices (Mellahi et al., 2013).

Those who argue that HR policies continue to diverge emphasize that contrasting country-specific institutions exert an influence over firms' HRM values and practices (Rowley and Benson, 2002). Thus, the US 'best practice' model of HRM cannot be characterized as 'the best' in countries with different cultural and institutional environments (Aycan, 2005). Although Asian companies have intensified their search for advanced Western HRM practices, Asian traditions, values, history and institutions are very different from the West, making Asian management and HRM quite different (Poon and Rowley, 2010).

Thus, it is important to examine the unique contextual factors prevailing in Pakistan in order to understand the HRM practices in MNC subsidiaries and local firms. Rosenzweig and Nohria (1994) argued that MNCs will not be able to implement policies that diverge significantly from local norms easily and that HR practices are likely to resemble local practices; however, this tendency varies from practice to practice. Moreover, Edwards and Kuruvilla (2005) argue that, in order to understand the global-local question better, we need to understand how MNCs operate. The crux of the argument is that MNCs only standardize 
their HRM policies and practices if it contributes to their global strategy. However, if the host-country context, MNC's division of labour and global commodity chain considerations do not favour such standardization, the MNC will not standardize its HRM policies and practices (Tüselmann et al., 2008).

The only research that we are aware of that examines the convergence/divergence debate in case of subsidiaries of MNC subsidiaries in Pakistan argues that MNC regional headquarters officers sought to transform HRM in Pakistan in an effort to lead the market in a process of convergence with the intention of introducing successful strategic HRM policies from the West (Khilji, 2002). However, the study focused solely on multinational banks in Pakistan, providing evidence that organizations and the people they manage are well aware of HRM practices in the West. Following Boselie et al. (2009), we argue that, despite the institutional pressures in an economy, firms enjoy some leeway for HRM and have some freedom to decide the degree of adaptation; however, they often cannot afford to diverge substantively from their competitors' HRM practices.

\section{Pakistani context}

Pakistan is the world's sixth most populous country (190 million inhabitants); two thirds of Pakistanis are under the age of 30 (Statistics-PK, 2016). The institutional environment of a country, including its cultural norms, potentially has important implications for firms' HR policies. The unemployment rate is 5.6 per cent and female participation in the workforce is low. The literacy rate is 58 per cent (Ministry-of-Finance, 2015). In year 2013-14, 0.31 million students were enrolled in 3,300 technical and vocational institutes in the country. In the higher education sector, 1.60 million students were enrolled in 161 universities. Thus, firms in Pakistan have access to skilled as well as unskilled workers to recruit from, potentially influencing the types of HR practices that local firms and MNC adopt. 
In the past few decades, governments of Pakistan have encouraged foreign direct investment (FDI), liberalization, de-regulation and privatization. The Government has, for example, granted tax holidays for foreign investors, helping total inward FDI reach $\$ 750.9$ million in 2015 and $\$ 2979$ million in total. These characteristics and the FDI figures illustrate the importance of FDI to Pakistan and highlight the potential opportunities for local firms to emulate MNCs' HPWS practices.

Trade unions play almost no role in the economy: only 6.3 per cent of the workforce is unionized and a mere 2.2 per cent have a collective bargaining agent. The Industrial Relations Act 2010 does not allow any role to unions in retention, suspension, dismissal or laying off of employees (Jhatial et al., 2014), enabling companies to implement the HR practices that they deem to be most appropriate. Moreover, Paik et al. (2011) argue that the institutional environment provides flexibility and options to MNCs to select whichever management practices are most appropriate for their operations. The regulatory institutional environment in Pakistan provides no strong requirements in terms of HRM policies that foreign firms must implement; foreign firms are unlikely to copy local firms' HR practices in a process of mimetic isomorphism as MNCs will not perceive local firms' practices to be superior to their own.

National culture, including religion, plays an important role in the type of HRM policies and practices being utilized in Asian economies (Al-Hamadi et al., 2007, Mellahi, 2007). Pakistan's culture has been classified as collectivist, high on power distance, hierarchical authority, and there is a preference for uncertainty avoidance and a restrained society (Iqbal et al., 2018). Factors such as connection, cronyism, corruption, deference to seniors are strong national characteristics. Family and social relationships take preference over rules and regulations and organizational life (Hofstede et al., 2010, Jhatial et al., 2014). 
In general, such factors are likely to influence firms' HRM practices. In particular, MNCs may be more likely than domestic companies to implement specific HRM policies.

\section{Hypothesis development}

This section develops hypotheses to examine the differences, if any, between key HPWS practices in subsidiaries of MNC's and domestic firms in Pakistan, a country with a distinctive institutional and cultural context. There is no consensus on which practices constitute HPWS; we, therefore, draw on HPWS literature and select the following practices: selective hiring and sophisticated selection, extensive training and development, employee involvement and participation, high compensation contingent on performance, performance review, appraisal and career development (Marchington and Wilkinson, 2008, Guest et al., 2003, Guthrie et al., 2009, Ramadani et al., 2013).

\section{Selective hiring and sophisticated selection}

Attracting high-quality candidates and using sophisticated techniques to select them are central to high performance paradigm (Marchington and Wilkinson, 2008). The literature on MNCs highlights that in an effort to recruit and select the best talent to fulfil their competency requirements MNCs often employ global best practice in their hiring and selection process (Garavan et al., 2012). A sophisticated recruitment system is needed to differentiate their employment offering from the domestic firms and to identify a personorganization fit (McDonnell et al., 2010, Vaiman and Brewster, 2015). However either to incorporate a sophisticated approach to recruitment or selection in the subsidiary depends upon the corporate strategy of the MNC (Mahmood, 2015).

In local firms, a person's social circle either based on close family relationships or a wider social network can play an important role in selection and hiring decisions (Saher and 
Mayrhofer, 2014). In Pakistan, a social elite has emerged as corporate entities rely on specific educational institutions that cater to the needs of the elite, creating a barrier for other candidates to apply to MNC subsidiaries and well-known domestic firms (Khilji and Wang, 2006). The political, military, civil and social elite in Pakistan have been shown to use employment opportunities to oblige their social network, supporters and punish opponents. Some evidence suggest that such a mind-set is true for private businesses (Jhatial et al., 2014). Thus, some evidence suggests that hiring and selection may be linked to sifarish (that is, personal connections or contacts that are used to benefit each other) (Mangi et al., 2012). As a result, recruitment and selection decisions may often not be based on merit, but on connections.

However, other evidence indicates that Pakistani companies are adopting more meritbased recruitment and selection practices (Ali and Brandl, 2017). Recently almost all the subsidiaries of MNC and major domestic firms have started advertising vacancies online and applicants can apply on-line, suggesting that firms appoint the most suitable rather than the most well-connected applicant to the job. Thus, we hypothesize:

H1: There will be no differences between MNC subsidiaries and domestic firms in Pakistan in their recruitment and selection practices.

\section{Extensive training, learning and development}

The provision of training opportunities to employees to improve their knowledge and problem-solving abilities is an important part of HPWS (Pfeffer, 1998). MNCs depend on the development of global workers; thus they often focus on soft HRM policies and practices that lead to the overall development of employees' human and social capital as well as their cultural intelligence so that they can operate, potentially, across the globe (Bozkurt and Mohr, 2011, Tatoglu et al., 2016). 
Although several governments in Pakistan have prioritized skill development, these priorities may not have influenced firm activities. The existing evidence indicates that $\mathrm{MNC}$ subsidiaries provide better training and career opportunities to workers in Pakistan (Khilji and Wang, 2006). This may reflect a sifarish culture to offer training, learning and development opportunities to those managers who are well connected rather than to those who merit them or to a wide group of employees. We, therefore, hypothesize that:

H2: MNC subsidiaries in Pakistan are more likely than domestic firms to provide training, learning and development opportunities to their employees.

\section{Employee involvement and participation}

Employee involvement and participation is one of the most important HPWS practices (Marchington and Wilkinson, 2008). The practice differentiates traditional mechanistic jobs from more skilled work (Beltrán-Martín et al., 2008). Mellahi et al. (2013) provide evidence that MNC's subsidiaries are more likely to encourage employee involvement and participation as compared to domestic firms. Williams and Lee (2016) provide evidence that MNC subsidiaries in South Korea provide a formal and extensive platform of employee involvement and participation as it facilitates knowledge sharing. Lavelle et al.'s (2010) study of MNCs in Ireland concluded that MNCs extensively use direct and indirect voice mechanisms. Indeed, employee involvement and participation has been considered as a critical element in MNCs' foreign operations in different cultural contexts (Pudelko and Harzing, 2007b).

The evidence on the extent of employee involvement and participation in Pakistani firms is mixed. Some evidence suggests that, in general, Pakistani firms provide limited information to employees, do not delegate authority to them, and do not enable them to participate in decision making (Khilji, 2002, Khilji and Wang, 2006). In this view, a typical 
Pakistani firm, reflecting high power distances, has a hierarchical structure and is highly formalized and centralized (Mangi et al., 2012). However, other evidence suggests that Pakistani firms are increasingly adopting HRM practices that promote participation (Miah and Bird, 2007). Based on the latter evidence, we hypothesize that:

H3: There will be no differences between MNC subsidiaries and domestic firms in Pakistan in their employee involvement and participation HRM practices.

\section{Performance review, appraisal and career development}

Performance appraisal is a systematic process in which firms assess an employee's performance and productivity against pre-set standards and organizational goals. Performance appraisal and career development are key aspects of HPWS and are used to enhance employees' skills and motivation (Macky and Boxall, 2007, Jiang et al., 2012). Increasingly evidence is emerging that indicates that performance appraisal is becoming standardized across MNCs (Edwards et al., 2016, Mellahi et al., 2016).

In Pakistan, the evidence suggests that MNC subsidiaries emphasize the development of employees more than domestic firms do (Khilji and Wang, 2007). Moreover, domestic firms may find it difficult to implement performance reviews as they are likely to run counter to agrarian norms of mutual expectations, exchange of favours and social network ties as well as other cultural values, such as the acceptance of differences in status (Ali and Brandl, 2017). Consequently, we hypothesize that

H4: MNC subsidiaries will be more likely to implement performance reviews, appraisals and career development reviews than domestic firms. 


\section{Performance-related compensation}

Performance-related pay is a key HPWS practice (Marchington and Wilkinson, 2008).

It can be designed both for individuals and the team depending upon task interdependence and it can take several forms, such as profit sharing and stock options etc. (Shaw et al., 2002). Performance-based pay is becoming increasingly popular in the US and the Europe and is becoming popular in Asia (Chang, 2006). However, Farndale et al. (2014) note that MNCs as compared to domestic firms are more likely to offer contingent-pay schemes, such as profit sharing and stock options, to employees based on their performance. Findings from Mellahi et al. (2013) suggest that, in context of Turkey, MNC subsidiaries are more likely than domestic firms to offer performance-related pay. Other research suggests that performancerelated pay, in the shape of profit sharing and stock options, has become an international practice in MNCs (Ahrens et al., 2018).

Evidence on the prevalence of performance-related pay in Pakistan is mixed. Some indicates that pay in Pakistani firms is typically seniority based (Khilji, 2002), while other evidence indicates that some local firms are adopting variable pay that is dependent on employees' contributions (Khilji and Wang, 2006). Drawing on the evidence overall, we hypothesize that:

H5: MNC subsidiaries are more likely to offer performance-related pay than domestic firms.

Figure 1 sets out all of our hypothesized relationships.

Figure 1 about here 


\section{Sample, Research Design and Data Collection}

We targeted MNC subsidiaries and domestically owned workplaces in the banking, information technology and pharmaceutical sectors. All these sectors have enjoyed a steady inflow of FDI and a sizeable number of MNC subsidiaries operate in these sectors. The population for our sampling frame was identified by visiting the websites of the relevant industry trade associations. The respective trade associations from where the details of their members were identified are: Pakistan Bankers Association, The Software Export Board, Pakistan, and Pharmaceutical Manufacturers Association. The lists were comprehensive and provided the details of addresses and contact person in the relevant establishment.

All private sector establishments with 20 or more employees located in and around four major metropolitan cities of Islamabad, Rawalpindi, Lahore and Karachi were invited to participate in the research. In Pakistan, the majority of economic activity is centred on these cities. Some $251 \mathrm{MNC}$ subsidiaries and 830 establishments of domestic firms operate in these cities. The majority of the MNC subsidiaries were headquartered in the UK or the US. We contacted all of the 1081 workplaces in our population; some 392 agreed to participate in a face-to-face survey, leading to an overall response rate of 36.4 per cent. We received 131 responses from the participants working for MNC subsidiaries (response rate 52\%) and 261 responses from domestic firms (31\%). The respondents typically held titles such as factory general manager, plant manager and branch manager. All of the respondents were senior executives and have served their respective firms for number of years, making them familiar with HR practices.

Unfortunately, we do not have any information other than the address of workplaces. We cannot, therefore, check for a non-response bias in our sample by comparing some of the characteristics of our sample to those of the population. In addition, as we collected out data using a face-to-face survey, we do not have any 'late responders' to use as proxies for 'non- 
responders'. Our relatively high response rates underpin the validity of our research. Although the sample sizes for both groups of firms are relatively small, they both exceed the minimum number of 100 cases for logistic regressions (Long, 1997). Even though we have a high percentage of the total populations in our sample, our unequal sample sizes mean that our coefficient values and odds ratio estimates should be treated with some caution (King and Zeng, 2001; Nemes et al., 2009). In particular, our odds ratios may bigger/smaller than the true value for positive/negative ratios. Building on previous studies (Batt, 2002, Wright et al., 2005), we investigated the applicability of HPWS practices for the firms' non-managerial employees and the impact of these practices on performance. Relevant theory drives this choice, as HPWS practices are only likely to influence performance if they apply to nonmanagerial employees (Lawler III, 1986, Pfeffer, 1994). One of the paper's authors collected the data using structured face-to-face interviews with respondents at their premises. The respondents were highly educated professionals; the questionnaire was carefully designed and kept to the shortest possible length to ensure a good response rate and valid answers. On average, the structured interviews lasted 20 to 30 minutes per respondent. Respondents were encouraged to take their time to complete the answers to ensure accuracy.

\section{Measures}

\section{The independent variables}

All independent variables of the study were measured by using items adopted from earlier work (Guest et al., 2003, Guthrie et al., 2009, Wright et al., 2003, Ramadani et al., 2013, Macky and Boxall, 2007). All items were measured on five point Likert scale.

Selective hiring and sophisticated selection (recruitment) was operationalized using three items: How often does your recruitment process generate as many good/qualified applicants as you need? Are one or more employment tests (e.g. skills tests, aptitude tests, 
mental/ cognitive ability tests) used prior to hiring? Is there a deliberate attempt to provide a preview of what work in the organization will be like, including more negative aspects as part of recruitment \& selection process?

Extensive training, learning and development (training) was operationalized by a four-item construct: Have non-managerial employees been trained in variety of jobs or skills (are cross trained) and /or routinely perform more than one job (are cross utilized); received intensive/ extensive training in company specific skills (e.g. task or firm specific training); received intensive/extensive training in generic skills (e.g. problem solving, communication skills, etc.). Your company places a great deal of importance on training.

Employee involvement and participation (employee involvement). The practice was operationalized using four items: are employees involved in programmes designed to elicit participation and employee input (e.g. quality circles, problem solving or similar groups); provided with relevant operating performance information (e.g. quality, productivity, etc.); provided with relevant strategic information (e.g. strategic mission, goals, tactics, competitor information etc.); organized in self-directed teams.

Performance review, appraisal and career development (performance appraisal) was operationalized using four items: employees receive formal performance appraisal or evaluation on a routine basis; employees receive formal performance feedback from more than one source (i.e. feedback from several individuals such as supervisors, peers etc.). A proportion of non-managerial employees pay is determined by performance appraisal. The Performance feedback provides information on how they do their job.

High compensation contingent on performance (compensation) was measured using three items: employees can participate in profit sharing or share ownership schemes based on their job performance or team performance; are they offered additional pay or have they been 
offered a pay rise in the past year as a result of job performance or work in team; are employees offered some sort of cash incentive?

Drawing on previous studies, we controlled for the number of employees and age of the firm in our analysis.

\section{The dependent variable}

Following Mellahi et al. (2013), we assigned a value of zero to multinational subsidiaries and a value of one to domestic companies for our categorical dependent variable. In other words, our dependent variable is the dichotomous variable of ownership; that is, MNC subsidiary or local establishment.

\section{Analysis}

We ran a series of binary logistic regression models to test the hypothesized relationships. The regression coefficient estimates the impact of an independent variable on the probability of an event occurring. There is no suggestion of multicollinearity between predictor variables. The descriptive statistics with pairwise correlations, values for cconvergent and discriminant reliability are provided in Table 1.

Insert Table 1 about here

The convergent validity of all the constructs is established as AVE $>0.50$ and the discriminant validity of all the constructs is established, as the square root (AVE) > intercorrelations. We ran a confirmatory factor analysis on the five factor solution. The five factor confirmatory factor analysis yielded the best fit for the data (Chi-Square $=280.30, \mathrm{df}=$ $20, \mathrm{CMIN} / \mathrm{df}=1.67, \mathrm{GFI}=0.96, \mathrm{RMSEA}=0.05)$. The CFA confirmed our five HPWS 
policies (selective hiring and sophisticated selection; extensive training, learning and development; employee involvement and participation; performance review, appraisal and career development; and high compensation contingent on performance). Table 2 provides further details regarding Cronbach alpha values, the items loadings for their relevant constructs, the AVEs and their composite reliabilities of the practices (the independent variables) and establishment of reliability and validity of constructs. The dependent variable is a single-item dichotomous variable; we did not, therefore, assess its reliability and validity.

Insert Table 2 about here

Table 3 shows the results of the logistic regressions. Multinational subsidiaries are the reference category. The binomial logistic model explains the variation in HRM practices between MNC subsidiaries and domestic Pakistani firms. A negative sign on the independent variable coefficient indicates that MNC subsidiaries use the relevant practice more than domestic firms; a positive sign indicates their relative greater use by domestic firms.

Insert Table 3 about here

We tested the individual effects of high performance HRM practices along with control variables in models 1 to 6 . All of the high performance HRM practices as independent variables along with control variables were tested in model 6. All seven models have significant $x^{2}$ values $(p<.001)$. All the models have good fit with correct ratios ranging from .68 to .72 . The Hosmer and Lemeshow value for all the models was non-significant, confirming the models' goodness of fit. Pseudo $R^{2}$ values ranged from .16 to .25 in models 1 
to 5 that include the individual high performance HRM practices, and .28 in model 6 that incorporates all the high performance HRM practices.

\section{Results}

As hypothesized by $\mathrm{H} 1$, the coefficient of selective hiring and sophisticated selection (recruitment) is positive, but not statistically significant in models 2 and 6, thus failing to support the hypothesis and suggesting that multinational subsidiaries and domestic firms do not differ with respect to their use of the practice. The coefficient of extensive training, learning and development (training) is negative and statistically significant the 0.1 per-cent level in Model 2 and at the five-per-cent level in Model 6. Thus, MNC subsidiaries are more likely to provide extensive training, learning and development opportunities to their employees compared to domestic Pakistani firms.

With respect to employee involvement and participation (employee involvement) (hypothesis 3), the individual practice model (Model 3) indicates a negative and statistically significant coefficient; however, this variable is not statistically significant in Model 6 . Keeping in view the improved explanatory power of the latter model, we consider its result to be more important. Hence we conclude that there are no statistically significant differences with respect to employee involvement and participation between MNC subsidiaries and domestic firms. In the case for the performance review, appraisal and career development the coefficient is negative and insignificant in case of individual practice in Model 4; however, the practice becomes significant in Model 6. Thus the overall model that contains all of the independent variables supports hypothesis 4 ( $\mathrm{MNC}$ subsidiaries are more likely than domestic firms to use performance appraisals.

As hypothesized by $\mathrm{H} 5$ the coefficient of high compensation contingent on performance (compensation) is negative and statistically significant at the 0.1 per-cent level 
in models 5 and 6 . Thus the results suggest that MNC subsidiaries are more likely to provide high compensation to their employees than domestic firms. However, overall, the mean values for this practice indicates that the surveyed companies use this practice infrequently in Pakistan.

\section{Discussion and Conclusion}

We examined the HPWS practices of MNC subsidiaries and domestic firms to understand similarities and differences between these two types of firm, revealing that host-country institutions influence the adoption of some of these practices in MNC subsidiaries. Isomorphism seems to affect some HRM practices in MNC subsidiaries in Pakistan. Thus no statistically significant differences were observed between the two types of firms with respect to 1) selective hiring and selection and 2) employee involvement and participation. Our finding of no statistically significant differences between MNC subsidiaries and local firm in terms of employee involvement and participation are in line with the previous research that indicates that the practice is increasingly gaining popularity in Asian countries (Torrington and Hall, 1998, Debroux, 2014, Miah and Bird, 2007), despite the marginal role that unions play in Pakistan.

Performance reviews are more likely to be used, in a statistically significant way, by MNC subsidiaries than by domestic firms. We argued that Pakistani culture reflects agrarian values with society expecting mutual favours and the maintenance of one's social network at the expense, potentially, of praising those outside it (Ali and Brandl, 2017). Conforming to these social norms, domestic firms seem less interested in the strict implementation of performance review practices.

Our findings also indicate that institutions play a role in domestic firms' implementation of extensive training and development policies: MNC subsidiaries are more 
likely to offer training opportunities to employees. These findings support the view that a sifarish culture affects many Pakistani firms, limiting the training and development opportunities for many employees.

In the case of compensation contingent on performance, the evidence reveals that MNC subsidiaries are more likely to implement the practice. Once again, this suggests that sifarish cultural norms lead managers to prioritize existing seniority and contacts at work rather than to open up compensation to more transparent policies that are likely to reward employees to a greater extent on merit (Jhatial et al., 2014).

An important argument of our study was that the high performance HRM model has gained an institutional status as a best practice US model. This has prompted some firms worldwide to organize their HRM practices on HPWS patterns. However, does a model that has its roots in US institutions have universalistic appeal? Do firms in other institutional settings accept the HPWS model as best practice? We found no evidence of complete convergence to the US model of HPWS in MNCs subsidiaries or domestic firms in Pakistan. An examination of individual practices in our case helped us to segregate the practices which were more localized by MNC subsidiaries and the ones which were integrated to the bestpractice US model. Though our basis of comparison was the HPWS model, we found support for the duality perspective in convergence/divergence debate. In line with the wider findings in the literature (Brewster et al., 2008, Mellahi et al., 2013, Myloni et al., 2007, Brewster et al., 2016), our results support the argument that there are various forces at play and HRM practice is subject to various institutional, especially normative, pressures both from host and home country context.

Our findings have some practical implications for firms in Pakistan. They can help MNC subsidiary managers to better understand the situation of local context and their standing vis-à-vis HPWS in Pakistan and in a similar way the local managers to establish 
their benchmarks for assessing the HRM status and change in Pakistan as compared to a decade ago.

Our research has some limitations: our respondents were single managers in each firm; our approach reflected, however, the difficulties of obtaining multiple respondents across several firms and conforms to practices in many studies by focusing on key informants who have the relevant knowledge to answer our questions (De Cieri and Dowling, 1999). In addition, the number of domestic establishments is almost double that of MNC subsidiaries. The difference in sample sizes may result in 'false positives' in logistic regressions; in other words, our results may suggest a statistically significant difference between the two types of establishment (MNC and local), when none exists (Herrera and Gómez, 2008). However, we were able to gain high response rates for both samples and we conducted face-to-face surveys, helping to improve the validity and representativeness of our data. Therefore, our cross-sectoral study of foreign and domestic workplaces has been able to shed light on HR practices across important firms and has highlighted the areas of convergence and divergence in HRM practices across the two groups of workplace.

References:

AHMAD, M. \& ALLEN, M. 2015. High performance HRM and establishment performance in Pakistan: an empirical analysis. Employee Relations, 37, 506-524.

AHRENS, C., OEHMICHEN, J. \& WOLFF, M. 2018. Expatriates as influencers in global work arrangements: Their impact on foreign-subsidiary employees' ESOP participation. Journal of World Business, 53, 452-462.

AL-HAMADI, A. B., BUDHWAR, P. S. \& SHIPTON, H. 2007. Management of human resources in Oman. The international journal of human resource management, 18, 100-113.

ALI, Q. \& BRANDL, J. 2017. HRM Research in Pakistan: Existing Approaches and Future Directions. Journal of Management Sciences, 4, 170-192.

ALMOND, P. \& FERNER, A. 2006. American multinationals in Europe: Managing employment relations across national borders, Oxford University Press.

ASHFAQ, S., MAHMOOD, Z. \& AHMAD, M. 2013. Impact of work-life conflict and work over load on employee performance in banking sector of Pakistan. Middle-East Journal of Scientific Research, 14, 688-695.

AYCAN, Z. 2005. The interplay between cultural and institutional/structural contingencies in human resource management practices. The International Journal of Human Resource Management, 16, 1083-1119. 
BASHIR, S. \& KHATTAK, H. R. 2008. Impact of selected HR practices on perceived employee performance, a study of Public Sector Employees in Pakistan. European Journal of Social Sciences, 5, 243-252.

BATT, R. 2002. Managing customer services: Human resource practices, quit rates, and sales growth. Academy of management Journal, 45, 587-597.

BECKER, B. E. \& HUSELID, M. A. 1998. Human resources strategies, complementarities, and firm performance. SUNY Buffalo: Unpublished manuscript.

BELTRÁN-MARTíN, I., ROCA-PUIG, V., ESCRIG-TENA, A. \& BOU-LLUSAR, J. C. 2008. Human resource flexibility as a mediating variable between high performance work systems and performance. Journal of Management, 34, 1009-1044.

BJÖRKMAN, I., STAHL, G. K. \& VAARA, E. 2007. Cultural differences and capability transfer in crossborder acquisitions: The mediating roles of capability complementarity, absorptive capacity, and social integration. Journal of International Business Studies, 38, 658-672.

BOSELIE, P., BREWSTER, C., PAAUWE, J., BOON, C., PAAUWE, J., BOSELIE, P. \& DEN HARTOG, D. 2009. Institutional pressures and HRM: developing institutional fit. Personnel Review, 38, 492-508.

BOZKURT, Ö. \& MOHR, A. T. 2011. Forms of cross-border mobility and social capital in multinational enterprises. Human Resource Management Journal, 21, 138-155.

BREWSTER, C., MAYRHOFER, W. \& SMALE, A. 2016. Crossing the streams: HRM in multinational enterprises and comparative HRM. Human Resource Management Review, 26, 285-297.

BREWSTER, C. \& TREGASKIS, O. 2003. Convergence or divergence of contingent employment practices? Evidence of the role of MNCs in Europe. Multinational companies and global human resource strategies, 143-166.

BREWSTER, C., WOOD, G. \& BROOKES, M. 2008. Similarity, isomorphism or duality? Recent survey evidence on the human resource management policies of multinational corporations. British Journal of Management, 19, 320-342.

BREWSTER, R. 2011. The Remedy Gap: Institutional Design, Retaliation, and Trade Law Enforcement. Geo. Wash. L. Rev., 80, 102.

BUDHWAR, P. S., VARMA, A. \& PATEL, C. 2016. Convergence-divergence of HRM in the Asia-Pacific: Context-specific analysis and future research agenda. Human Resource Management Review, 26, 311-326.

CHANG, E. 2006. Individual pay for performance and commitment HR practices in South Korea. Journal of World Business, 41, 368-381.

CHEN, S., LAWLER, J. J. \& BAE, J. 2005. Convergence in human resource systems: A comparison of locally owned and MNC subsidiaries in Taiwan. Human Resource Management, 44, 237-256.

CHIANG, F., LEMANSKI, M. \& BIRTCH, M. (2017) 'The transfer and diffusion of HRM practices within MNCs: lessons learned and future research directions', International Journal of Human Resource Management, 28, 1, 234-258.

COOKE, F. L. 2011. Talent management in China. Global talent management, 132-153.

DE CIERI, H. \& DOWLING, P. J. 1999. Strategic human resource management in multinational enterprises: theoretical and empirical developments.

DEBROUX, P. 2014. Corporate social responsibility and sustainable development in Asia. Asian business and management: Theory, practice and perspectives, 139-158.

DIMAGGIO, P. \& POWELL, W. W. 1983. The iron cage revisited: Collective rationality and institutional isomorphism in organizational fields. American Sociological Review, 48, 147-160.

DOH, J. P., SMITH, R. R., STUMPF, S. A. \& TYMON, W. G. 2014. Emerging markets and regional patterns in talent management: the challenge of India and China.

EDWARDS, T. \& KURUVILLA, S. 2005. International HRM: national business systems, organizational politics and the international division of labour in MNCs. The International Journal of Human Resource Management, 16, 1-21.

EDWARDS, T., SÁNCHEZ-MANGAS, R., JALETTE, P., LAVELLE, J. \& MINBAEVA, D. 2016. Global standardization or national differentiation of HRM practices in multinational companies? A 
comparison of multinationals in five countries. Journal of International Business Studies, 47, 997-1021.

EDWARDS, T. \& ZHANG, M. 2008. Multinationals and national systems of employment relations: Innovators or adapters? The Global Diffusion of Human Resource Practices: Institutional and Cultural Limits. Emerald Group Publishing Limited.

ESPING-ANDERSEN, G. 1990. 4 The Three Political Economies of the Welfare State. International journal of sociology, 20, 92-123.

FARNDALE, E., BREWSTER, C. \& POUTSMA, E. 2014. Coordinated vs. liberal market HRM: the impact of institutionalization on multinational firms. International human resource management. Routledge.

FERNER, A. \& QUINTANILLA, J. 1998. Multinationals, national business systems and HRM: the enduring influence of national identity or a process of'Anglo-Saxonization'. International Journal of Human Resource Management, 9, 710-731.

FEY, C. F., MORGULIS-YAKUSHEV, S., PARK, H. J. \& BJÖRKMAN, I. 2009. Opening the black box of the relationship between HRM practices and firm performance: A comparison of MNE subsidiaries in the USA, Finland, and Russia. Journal of International Business Studies, 40, 690-712.

GARAVAN, T. N., CARBERY, R. \& ROCK, A. 2012. Mapping talent development: definition, scope and architecture. European journal of training and development, 36, 5-24.

GUEST, D. E., MICHIE, J., CONWAY, N. \& SHEEHAN, M. 2003. Human resource management and corporate performance in the UK. British journal of industrial relations, 41, 291-314.

GUTHRIE, J. P., FLOOD, P. C., LIU, W. \& MACCURTAIN, S. 2009. High performance work systems in Ireland: human resource and organizational outcomes. The International Journal of Human Resource Management, 20, 112-125.

HALL, P. A. \& SOSKICE, D. 2001. Varieties of capitalism: The institutional foundations of comparative advantage, OUP Oxford.

HOFSTEDE, G., HOFSTEDE, G. J. \& MINKOV, M. 2010. Cultures and organizations: Software of the mind. Revised and expanded. McGraw-Hill, New York.

HOUSE, R. J., HANGES, P. J., JAVIDAN, M., DORFMAN, P. W. \& GUPTA, V. 2004. Culture, leadership, and organizations: The GLOBE study of 62 societies, Sage publications.

JACKSON, G. \& DEEG, R. 2008. Comparing capitalisms: Understanding institutional diversity and its implications for international business. Journal of International Business Studies, 39, 540561.

JHATIAL, A. A., CORNELIUS, N. \& WALLACE, J. 2014. Rhetorics and realities of management practices in Pakistan: Colonial, post-colonial and post-9/11 influences. Business History, 56, 456-484.

JIANG, K., LEPAK, D. P., HU, J. \& BAER, J. C. 2012. How does human resource management influence organizational outcomes? A meta-analytic investigation of mediating mechanisms. Academy of management Journal, 55, 1264-1294.

KERR, C., HARBISON, F. H., DUNLOP, J. T. \& MYERS, C. A. 1960. Industrialism and industrial man. Int'I Lab. Rev., 82, 236.

KHILI, E. 2002. Modes of convergence and divergence: An integrative view of multinational practices in Pakistan. International Journal of Human Resource Management, 13, 232-253.

KHILI, S. E. \& WANG, X. 2006. 'Intended'and 'implemented'HRM: the missing linchpin in strategic human resource management research. The International Journal of Human Resource Management, 17, 1171-1189.

KOSTOVA, T., ROTH, K. \& DACIN, M. T. 2008. Institutional theory in the study of multinational corporations: A critique and new directions. Academy of management review, 33, 994-1006.

LAVELLE, J., GUNNIGLE, P. \& MCDONNELL, A. 2010. Patterning employee voice in multinational companies. Human relations, 63, 395-418.

LAWLER III, E. E. 1986. High-Involvement Management. Participative Strategies for Improving Organizational Performance, ERIC. 
LAWLER, J. J., CHEN, S.-J., WU, P.-C., BAE, J. \& BAI, B. 2011. High-performance work systems in foreign subsidiaries of American multinationals: An institutional model. Journal of International Business Studies, 42, 202-220.

LONG, J. S. (1997). Regression Models for Categorical and Limited Dependent Variables. Thousand Oaks, CA Sage

MA, S., SILVA, M. G., CALLAN, V. J. \& TRIGO, V. 2016. Control and commitment HR practices, job satisfaction and turnover intentions: a comparison between local and multinational firms in China. The International Journal of Human Resource Management, 27, 974-990.

MACKY, K. \& BOXALL, P. 2007. The relationship between 'high-performance work practices' and employee attitudes: an investigation of additive and interaction effects. The International Journal of Human Resource Management, 18, 537-567.

MAHMOOD, M. 2015. Strategy, structure, and HRM policy orientation: Employee recruitment and selection practices in multinational subsidiaries. Asia Pacific Journal of Human Resources, 53, 331-350.

MANGI, R. A., SHAH, A. \& GHUMRO, I. 2012. Human resource management practices in private sector organisations in Pakistan: study of cultural influences. Global Journal of Management and Business Research, 12, 20-30.

MARCHINGTON, M. \& WILKINSON, A. 2008. Human Resource Management at Work: People Management and Development, Chartered Institute of Personnel and Development.

MAYRHOFER, W., BREWSTER, C., MORLEY, M. J. \& LEDOLTER, J. 2011. Hearing a different drummer? Convergence of human resource management in Europe-A longitudinal analysis. Human Resource Management Review, 21, 50-67.

MCDONNELL, A., LAMARE, R., GUNNIGLE, P. \& LAVELLE, J. 2010. Developing tomorrow's leadersEvidence of global talent management in multinational enterprises. Journal of world business, 45, 150-160.

MELLAHI, K. 2007. The effect of regulations on HRM: private sector firms in Saudi Arabia. The International Journal of Human Resource Management, 18, 85-99.

MELLAHI, K., DEMIRBAG, M., COLLINGS, D. G., TATOGLU, E. \& HUGHES, M. 2013. Similarly different: a comparison of HRM practices in MNE subsidiaries and local firms in Turkey. The International Journal of Human Resource Management, 24, 2339-2368.

MELLAHI, K., FRYNAS, J. G. \& COLLINGS, D. G. 2016. Performance management practices within emerging market multinational enterprises: the case of Brazilian multinationals. The International Journal of Human Resource Management, 27, 876-905.

MIAH, M. K. \& BIRD, A. 2007. The impact of culture on HRM styles and firm performance: evidence from Japanese parents, Japanese subsidiaries/joint ventures and South Asian local companies. The International Journal of Human Resource Management, 18, 908-923.

MINISTRY-OF-FINANCE 2015. Economic Survey of Pakistan.

MYLONI, B., HARZING, A.-W. \& MIRZA, H. 2007. The effect of corporate-level organizational factors on the transfer of human resource management practices: European and US MNCs and their Greek subsidiaries. The International Journal of Human Resource Management, 18, 20572074.

NEMES, S., JONASSON, J. M., GENELL, A. and STEINECK, G. (2009) 'Bias in Odds Ratios by Logistic Regression Modelling and Sample Size', BMC Medical Research Methodology, 9.

PAAUWE, J. 2009. HRM and performance: Achievements, methodological issues and prospects. Journal of Management studies, 46, 129-142.

PAIK, Y., CHOW, I. H. S. \& VANCE, C. M. 2011. Interaction effects of globalization and institutional forces on international HRM practice: Illuminating the convergence-divergence debate. Thunderbird International Business Review, 53, 647-659.

PFEFFER, J. 1994. Competitive advantage through people. California management review, 36, 9-28.

PFEFFER, J. 1998. The human equation: Building profits by putting people first, Harvard Business Press. 
POON, I. H.-F. \& ROWLEY, C. 2010. Change in Asia: a review of management theory and research related to human resources. Asia Pacific Business Review, 16, 591-607.

POUTSMA, E., LIGTHART, P. E. \& VEERSMA, U. 2006. The diffusion of calculative and collaborative HRM practices in European firms. Industrial Relations: A Journal of Economy and Society, 45, 513-546.

PUDELKO, M. \& HARZING, A. W. 2007a. Country-of-origin, localization, or dominance effect? An empirical investigation of HRM practices in foreign subsidiaries. Human Resource Management, 46, 535-559.

PUDELKO, M. \& HARZING, A. W. 2007b. Country-of-origin, localization, or dominance effect? An empirical investigation of HRM practices in foreign subsidiaries. Human Resource Management: Published in Cooperation with the School of Business Administration, The University of Michigan and in alliance with the Society of Human Resources Management, 46, 535-559.

RAMADANI, V., GËRGURI, S., DANA, L.-P. \& TAŠAMINOVA, T. 2013. Women entrepreneurs in the Republic of Macedonia: waiting for directions. International Journal of Entrepreneurship and Small Business, 19, 95-121.

ROSENZWEIG, P. M. \& NOHRIA, N. 1994. Influences on human resource management practices in multinational corporations. Journal of international business studies, 25, 229-251.

ROWLEY, C. \& BENSON, J. 2002. Convergence and divergence in Asian human resource management. California management review, 44, 90-109.

SAHADEV, S. \& DEMIRBAG, M. 2011. Exploring variations in employment practices in the emerging economies of Europe: assessing the impact of foreign ownership and European integration. Human Resource Management Journal, 21, 395-414.

SAHER, N. \& MAYRHOFER, W. 2014. The role of Vartan Bhanji in implementing HRM practices in Pakistan. The International Journal of Human Resource Management, 25, 1881-1903.

SCOTT, W. R. 1995. Institutions and organizations, Sage Thousand Oaks, CA.

SCOTT, W. R. 2013. Institutions and organizations: Ideas, interests, and identities, Sage Publications.

SHAHZAD, K., BASHIR, S. \& RAMAY, M. I. 2008. Impact of HR practices on perceived performance of university teachers in Pakistan. International review of business research papers, 4, 302-315.

SHAW, J. D., GUPTA, N. \& DELERY, J. E. 2002. Pay dispersion and workforce performance: Moderating effects of incentives and interdependence. Strategic Management Journal, 23, 491-512.

SMITH, C. \& MEIKSINS, P. 1995. System, society and dominance effects in cross-national organisational analysis. Work, Employment \& Society, 9, 241-267.

STATISTICS-PK 2016. Pakistan Bureau of Statistics.

TATOGLU, E., GLAISTER, A. J. \& DEMIRBAG, M. 2016. Talent management motives and practices in an emerging market: A comparison between MNEs and local firms. Journal of World Business, 51, 278-293.

TORRINGTON, D. \& HALL, S. 1998. Human resource management and the personnel function, London: Routledge.

TÜSELMANN, H.-J., ALLEN, M. M., BARRETT, S. \& MCDONALD, F. 2008. Varieties and variability of employee relations approaches in US subsidiaries: country-of-origin effects and the level and type of industry internationalisation. The International Journal of Human Resource Management, 19, 1622-1635.

VAIMAN, V. \& BREWSTER, C. 2015. How far do cultural differences explain the differences between nations? Implications for HRM. The International Journal of Human Resource Management, 26, 151-164.

VANHALA, S., KAARELSON, T. \& ALAS, R. 2006. Converging human resource management: A comparison between Estonian and Finnish HRM. Baltic Journal of Management, 1, 82-101.

WILLIAMS, C. \& LEE, S. H. 2016. Knowledge flows in the emerging market MNC: The role of subsidiary HRM practices in Korean MNCs. International Business Review, 25, 233-243. 
WRIGHT, P. M., GARDNER, T. M. \& MOYNIHAN, L. M. 2003. The impact of HR practices on the performance of business units. Human Resource Management Journal, 13, 21-36.

WRIGHT, P. M., SNELL, S. A. \& DYER, L. 2005. New models of strategic HRM in a global context. The International Journal of Human Resource Management, 16, 875-881.

ZHU, Y., WARNER, M. \& ROWLEY, C. 2007. Human resource management with 'Asian'characteristics: a hybrid people-management system in East Asia. The international journal of human resource management, $18,745-768$. 
Table 1. Descriptive Statistics and Correlation Coefficients and AVEs (Convergent and Discriminant Reliability)

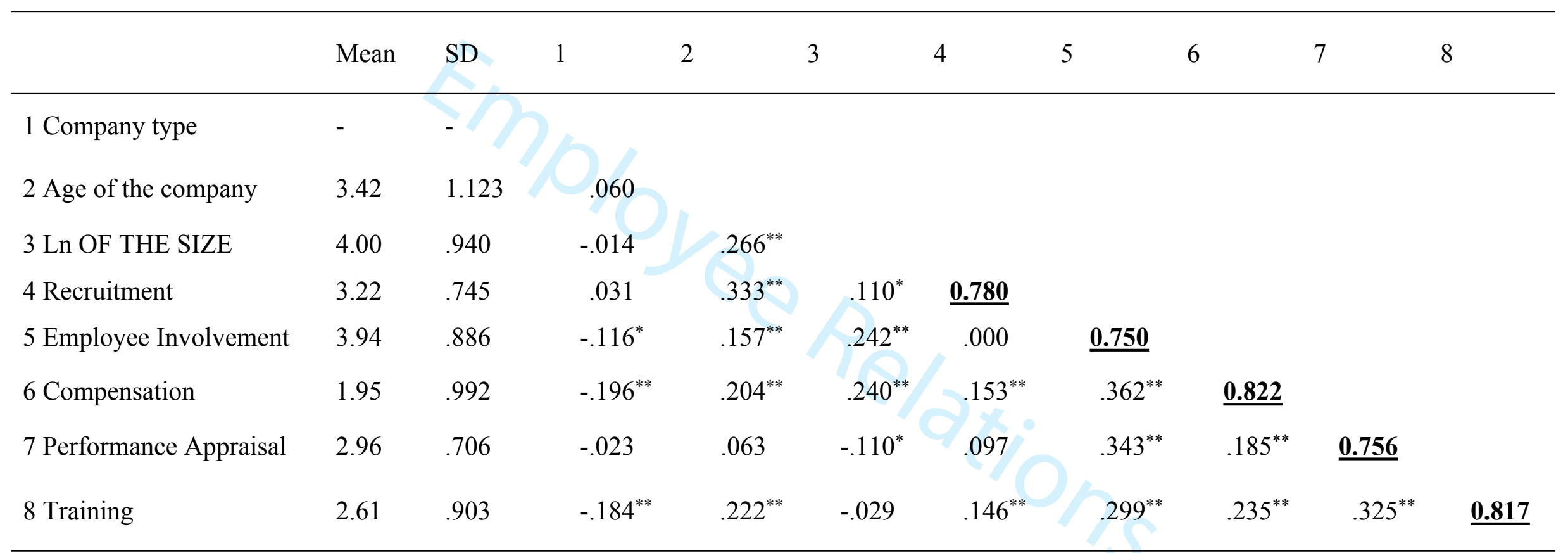

Note: The diagonal values are the Square root of AVEs of the relevant construct. These values should be greater than the inter-correlation to establish discriminant validity of the construct. The table shows that Discriminant Validity of all the constructs is established as the diagonal values i.e., Square root (AVE) $>$ inter-correlations. The convergent validity of all the constructs is established through AVE $>0.50$. Please further note that variable company type is a binary variable coded as 0 for MNC and 1 for domestic firm. As its binary in nature so mean and SD values are not provided.

‘**' indicates statistical significance at the five per cent level. 
Table 2 Reliability and Validity (Measurement Model):

\begin{tabular}{|c|c|c|c|c|c|}
\hline Construct (items) & Factor Loading & $\begin{array}{l}\text { Cronbach Alpha } \\
\text { (CR Composite } \\
\text { Reliability) }\end{array}$ & AVE & Convergent Validity & Discriminant Validity \\
\hline \multicolumn{2}{|c|}{ Recruitment -4 Items } & \multirow{4}{*}{$\begin{array}{c}0.723 \\
(0.817)\end{array}$} & \multirow{4}{*}{0.608} & \multirow{4}{*}{ Established AVE $>0.50$} & \multirow{4}{*}{$\begin{array}{r}\text { Established (Sqrt (AVE) }>\text { inter- } \\
\text { correlation) }\end{array}$} \\
\hline Rec1 & 0.858 & & & & \\
\hline $\operatorname{Rec} 2$ & 0.884 & & & & \\
\hline Rec3 & 0.554 & & & & \\
\hline \multicolumn{2}{|c|}{ Employee Involvement - 4 Items } & \multirow{5}{*}{$\begin{array}{c}0.760 \\
(0.743)\end{array}$} & \multirow{5}{*}{0.562} & \multirow{5}{*}{ Established AVE $>0.50$} & \multirow{5}{*}{ As above } \\
\hline EI1 & 0.891 & & & & \\
\hline EI2 & 0.439 & & & & \\
\hline EI3 & 0.817 & & & & \\
\hline EI4 & 0.771 & & & & \\
\hline \multicolumn{2}{|c|}{ Compensation -3 Items } & \multirow{4}{*}{$\begin{array}{c}0.707 \\
(0.809) \\
\end{array}$} & \multirow{4}{*}{0.676} & \multirow{4}{*}{ Established AVE $>0.50$} & \multirow{4}{*}{ As above } \\
\hline Comp1 & 0.838 & & & & \\
\hline Comp2 & 0.868 & & & & \\
\hline Comp3 & 0.757 & & & & \\
\hline \multicolumn{2}{|c|}{ Performance Appraisal - 4 Items } & \multirow{5}{*}{$\begin{array}{c}0.705 \\
(0.753)\end{array}$} & \multirow{5}{*}{0.572} & \multirow{5}{*}{ Established AVE $>0.50$} & \multirow{5}{*}{ As above } \\
\hline PA1 & 0.849 & & & & \\
\hline PA2 & 0.898 & & & & \\
\hline PA3 & 0.418 & & & & \\
\hline PA4 & 0.765 & & & & \\
\hline \multicolumn{2}{|l|}{ Training -4 Items } & \multirow{5}{*}{$\begin{array}{c}0.848 \\
(0.843)\end{array}$} & \multirow{5}{*}{0.668} & \multirow{5}{*}{ Established AVE $>0.50$} & \multirow{5}{*}{ As above } \\
\hline Train1 & 0.930 & & & & \\
\hline Train2 & 0.878 & & & & \\
\hline Train3 & 0.529 & & & & \\
\hline Train4 & 0.870 & & & & \\
\hline
\end{tabular}

Note. In above table; Rec1, Rec2, Rec3 are the items of Recruitment; EI1, EI2, EI3 are the items of Employee Involvement; Comp1, Comp2 and Comp3 are the items of Compensation; PA1, PA2, PA3 and PA4 are the items of Performance Appraisal, Train1, Train2, Train3, Train4 are the items of Training. The second column shows their loadings on their main construct. The Dependent Variable (Company Type) is dichotomous and single item construct, therefore, no measurement model for this construct. 
Table 3 Results of logistic regressions

\begin{tabular}{|c|c|c|c|c|c|c|}
\hline Variable Name & Model 1 & Model 2 & Model 3 & Model 4 & Model 5 & Model 6 \\
\hline Recruitment & .02 & & & & & .12 \\
\hline Training & & $-1.14 * * *$ & & & & $-.95 * *$ \\
\hline Employee Involvement & & & $-.32 * *$ & & & -.14 \\
\hline Performance Appraisal & & & & -.05 & & $-.42 * *$ \\
\hline Compensation & & & & & $-.72 * * *$ & $-.71 * * *$ \\
\hline Log Size & $-.81 * * *$ & $-.81 * * *$ & $-.75^{* * *}$ & $-.81 * * *$ & $-.84 * * *$ & $-.81 * * *$ \\
\hline Age & .11 & $.19^{*}$ & .12 & .10 & $.20^{*}$ & $.22 *$ \\
\hline Model $X^{2}$ & $49.04 * * *$ & $59.08 * * *$ & $54.60 * * *$ & $49.02 * * *$ & $79.33 * * *$ & $89.00 * * *$ \\
\hline Pseudo $R^{2}$ & .16 & .19 & .18 & .16 & .25 & .28 \\
\hline Correct Ratio & .68 & .70 & .69 & .68 & .72 & .71 \\
\hline Hosmer and Lemeshow & .71 & .95 & .69 & .71 & .20 & .35 \\
\hline
\end{tabular}

Notes: The dependent variable is the type of company i.e., MNC subsidiary or local workplace. MNC subsidiary were assigned a value of ' 0 '; local establishments, ' 1 '. $\mathrm{N}=392$; MNC subsidiaries $=131$; local workplaces $=261$. Negative signs indicate MNC subsidiaries' greater use relative use of the HRM practices, while positive signs indicate local establishments' greater use of the HRM policy. $* \mathrm{p}<0.1 ; * * \mathrm{p}<0.05 ; * * \mathrm{p}<.001$ 
Figure 1 Research Framework

\section{High Performance Work}

System Practices

Selective hiring and

sophisticated selection

Extensive training, learning

and development

Employee involvement and participation

Performance review, appraisal and career development

Performance-related

Control

Variables

Firm Size

MNC

Subsidiary

Domestic Firm

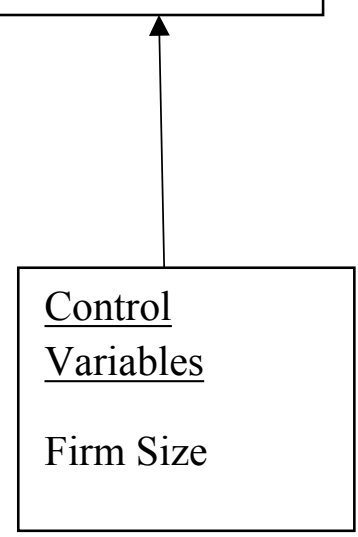

